\title{
Wax Models in Dermatology: Updated through 2019
}

Lawrence Parish

Thomas Jefferson Univeristy

Follow this and additional works at: https://jdc.jefferson.edu/dcbfp

Part of the Dermatology Commons

Let us know how access to this document benefits you

\section{Recommended Citation}

Parish, Lawrence, "Wax Models in Dermatology: Updated through 2019" (2020). Department of Dermatology and Cutaneous Biology Faculty Papers. Paper 130.

https://jdc.jefferson.edu/dcbfp/130

This Article is brought to you for free and open access by the Jefferson Digital Commons. The Jefferson Digital Commons is a service of Thomas Jefferson University's Center for Teaching and Learning (CTL). The Commons is a showcase for Jefferson books and journals, peer-reviewed scholarly publications, unique historical collections from the University archives, and teaching tools. The Jefferson Digital Commons allows researchers and interested readers anywhere in the world to learn about and keep up to date with Jefferson scholarship. This article has been accepted for inclusion in Department of Dermatology and Cutaneous Biology Faculty Papers by an authorized administrator of the Jefferson Digital Commons. For more information, please contact: JeffersonDigitalCommons@jefferson.edu. 
Wax models in dermatology: Updated through 2019

This is an updated version of an article published in 1991, in Transactions and Studies of the College of Physicians of Philadelphia, Volume 12, Issue 1, Pages 29-74 https://pubmed.ncbi.nlm.nih.gov/2038761/

Wax models have occupied an unique position in the teaching of dermatology. While watercolor depictions of skin lesions and later photographic illustrations have been used, the wax model offers an unique presentation of the morphology, often not captured by other methods. This is illustrated by the fact that Mrs. Taussard's Wax Museums existed in many capital cities world-wide.

Much has already been written about the unfortunate fate of many of these collections following the introduction of Kodachrome slides in the early 1950s, when department museums or collections were considered no longer useful. Some models went to historical collections, a few were saved to continue their didatic purpose, and still others met untimely demises. ${ }^{2}$

There has been renewed interest in the preservation of these models in recent years, from dermatologists and historians alike, and this has led to increasing efforts to document the origin, migration, exhibition, and maintenance of these collections moving forward. Wonderful museums or collections of moulages can still be found in the Mütter Museum of the College of Physicians of Philadelphia, the Gordon Museum at Guy's Hospital in London, the Collection at l'Hôpital Saint Louis in Paris, and the Was Model Museum in Zurich. The Olivade wax models are the prototype of how a dedicated group of physicans and lay people can create a new museum with models that had almost been eradicated by the Franco regime in Spain. 
Wax models in dermatology: Updated through 2019

Our mission for this study is to report on our findings of the existence and whereabouts of dermatologic wax model since the 1990 survey. Even with the advent of the internet and the interest generated for preserving these wonderful illustrations of dermatologic conditions, many collections have remained unknown or even dismantled. Fortuitously, at least one has been resurrected.

\section{Collections in North America}

Temple, Texas

Scott \& White Memorial Hospital hosts one of the largest collections of wax medical models in the United States. The collection was created jointly by the husband and wife team Kenneth and Margaret Phillips, who were active in the Department of Art at Scott \& White between 1932 and $1955 .^{3}$ The models were created by first producing a watercolor sketch of the specimen, then filling a plaster mold of the specimen with the wax mixture, and finally painting the model with oil paints, using the watercolor sketch as a reference. ${ }^{4}$ The majority of the moulages were stored and displayed in the Department of Anatomic Pathology when not being presented at exhibitions or in use as teaching tools. In 2014, the McLane Children's Hospital Scott and White was awarded a \$20,000 grant by the National Network of Libraries of Medicine for the "Moulage 3-D Digitization and Preservation Project." 5 The project funded the initial creation and online hosting of digital 3-D models of 300 of the medical moulages in the Scott \& White collection, ${ }^{6}$ as well as the appropriate storage of the models in acid-free wrapping materials in a climatecontrolled area. 
Wax models in dermatology: Updated through 2019

\section{Collections in South America}

Rosario, Argentina

In October 1922, Dr. Enrique P. Fidanza, a Professor of Dermatology at the Hospital Nacional del Centenario, was charged with the task of traveling to L'Hôpital Saint-Louis to obtain a number of wax models for use in the instruction of dermatology at the School of Medicine, National University of Rosario (Argentina). ${ }^{7-9}$ This original set of around 100 moulages was created by Louis Niclet and is estimated to have been worth approximately 1000 dollars; 258 additional pieces produced by Argentine craftsmen, including Alba Ramirez and G. Rouzaut, were added to the collection in later years. The collection was originally exhibited in the Department of Dermatology, prior to its transition to the Department of Pathology at an unknown date. In 1998, funds were obtained to commission an Argentine professional skilled in this craft to restore a percentage of the collection's pieces. The models were subsequently classified according to different dermatological diseases to facilitate the preparation of the models for exhibition in the Department of Pathology.

\section{Collections in Europe}

\section{Madrid, Spain}

A collection at the Olavide Museum in Madrid, Spain has only recently been recovered. Founded by Spanish dermatologist José Eugenio Olavide in 1882, this collection was originally located at the Museo Anatomo-Patológico, Cromo-Litográfico y Microscópico of the Hospital San Juan de Dios. ${ }^{10}$ In 1897, the Hospital San Juan de Dios changed locations. This move proved to be disastrous for many of the museum's now lost 
exhibits; the exception was the wax models and their corresponding documentation, many of which remain to this day. ${ }^{10}$

From surviving documents, it is garnered that most of the early figures in this set were produced and exhibited in a mixed museum setting by Enrique Zofío, a civilian anatomical sculptor contracted by the army with a still unclear working relationship to the Hospital San Juan de Dios from 1880-1897. ${ }^{11}$ Zofío worked out of the Hospital Militar de Madrid-Carabanchel for much of his career, but it is unclear if it is at this location, or at the Olavide Museum's second home, where he created his numerous wax figures. ${ }^{12}$ This detail is important given that the Hospital Militar de Madrid-Carabanchel suffered a fire on February 8, 1889, taking up in its flames around 1151 pieces housed at this preparatory facility, although the nature of the figures lost (and how many specifically were dermatologic in nature, or even wax models in general) is not documented. ${ }^{12}$ Therefore, the number of moulages the museum possessed at it's peak remains in question, with estimates ranging from 400 to 1,500 pieces. This calculation is further complicated by the fact that it is unclear when sculptor José Barta y Bernadotta, a purported successor of Zofío, began to craft additional models for the the Olavide museum, as his creations (in contrast to Zofíos extensive medical histories) lack any descriptions beyond their titles. ${ }^{11}$

The museum declined in the years to follow, culminating in its closing in late 1967/early 1968. Fortunately, Rafael López Álvarez, one of the museum's skin disease moulagers, took charge of packing the models away in crates to be stored in a previously unknown 
Wax models in dermatology: Updated through 2019

location. ${ }^{13}$ After a lengthy search spanning multiple decades, more than 220 of these crates were finally found on December 27, 2005, in warehouse storage area of the Hospital del Niño Jesús. The Spanish Academy of Dermatology and Venereology (AEDV) has committed to the classification and funding to complete restoration of the models, although hundreds of crates remain to be opened. Forty of these recovered models were triumphantly exhibited during the XXXIV National Congress of the AEDV, exposing new generations of dermatologists to the beauty of these works of art. At present, 19 dermatologic moulages can be seen at the newly invigorated Olavide Museum, located at Pavilion 8 of the Faculty of Medicine of the Complutense University of Madrid. ${ }^{14}$

\section{Belgrade, Serbia}

The Belgrade moulage collection has its origins with the founding of Belgrade University's School of Medicine and the Institute of Dermatology and Venereology (IDV) in $1920 .{ }^{15}$ Djordje Djordjevic, the first professor of dermatovenereology at the School of Medicine and the first director of the IDV, ${ }^{15,16}$ most likely acquired the set's first figures while completing his medical studies in Hamburg and Vienna. ${ }^{17}$ Although no record of a name exists, IDV staff list records indicate the presence of a moulageur as early as $1931 .^{15}$ The first official moulageur to have contributed to the Belgrade collection, as evidenced by his signature on 178 of the collection's pieces, was Dr. Sergej Alisov. Although few details on his life can be found, it appears he was of Russian descent and active from 1925-1940, subsequently migrating to Germany in $1943 .{ }^{17}$ Vojislav Sikoparija followed as official moulageur at the IDV in 1950. His contribution 
totals 103 pieces, and his retirement in 1958 marks the year the last moulage in this collection was crafted.

As it stands, the Belgrade collection is currently composed of 350 pieces, although the set is estimated to have originally been much greater in number, and it is theorized that many were destroyed during occupation of the IDV during World War II, and others still during the IDV's move from it's previous location. ${ }^{17}$

At present, the moulages are carefully displayed in the Dermatology Hospital's library within wooden glass-door display cabinets isolated from moisture, with black drapes dressing the windows to protect the figures from sunlight.

\section{Collections in Asia}

\section{Mumbai, India}

The moulages at the Sir Jamshetjee Jeejeebhoy (JJ) Hospital in Mumbai can be traced back to two Englishmen in the 1800s. The first, renowned wax modeler Joseph Towne, is creator of the world-famous collection at Guy's Hospital, London (Gordon Museum). ${ }^{18}$ The second is anatomical artist Henry Vandyke Carter, most notable for his illustrations of the book, Gray's Anatomy, who joined the Bombay Medical Service in 1858, and was made professor of Anatomy and Physiology at Grant Medical College and assistant surgeon at the affiliated JJ Hospital later that year. ${ }^{19}$ By 1877, Carter was appointed Principal of Grant Medical College and Physician of the JJ Hospital. ${ }^{19}$ It is around this time that Carter, having worked in London during Towne's prime and therefore familiar 
with his work, most likely ordered the set of moulages that are now present at the JJ Hospital.

The majority of the moulages in this collection (61 total) can be found in the pathology museum in the same building that houses the JJ Hospital Department of Pathology, although it is unclear how they originally arrived at this location. The remaining figures (17 total) depict dermatologic conditions. The earliest recollection of where this minority was exhibited is in 1967, when they are said to have been stored in glass cabinets in the building that housed the outpatient department, separate from the main hospital campus. ${ }^{19}$ In 2005, the dermatology outpatient department rejoins the main outpatient building, at which point this subset of moulages are rediscovered and similarly displayed in glass cabinets in their new home. These 17 models are considered to be fairly well-preserved, in stark contrast to the majority of this collection in the pathology museum, of which only about three are in comparable condition.

\section{$\underline{\text { Conclusion }}$}

\section{References}

1. Haviland TN, Parish LC. A brief account of the use of wax models in the study of medicine. J Hist Med Allied Sci. 1970;25:52-75

2. Parish LC, Worden G, Witkowski JA, et al. Wax models in dermatology. Trans Stud Col Physic Phila. 1991;13:29-74

3. Mears M, Feaster V. Wax medical moulages: the Scottand White Collection, 19321955. Tx Med. 1993;89:13-15.

4. Mears M, Feaster V. The wax medical moulage collection at Scott and White Memorial Hospital. Int J Dermatol. 1994;33(6):446-447.

5. https://sketchfab.com/swmoulage 
6. https://nnlm.gov/scr/funding/funded/6865

7. 5. Araya R. Memories 1922 and 1923. Facultad de Ciencias Médicas. Farmacia y Ramos Menores. [in Spanish] 1924;1:48-49.

8. Araya R. Endownment of Moulages. Memory 1924. Facultad de Ciencias Médicas. Farmacia y Ramos Menores. [in Spanish] 1925;2:44-45.

9. Berra H, Alloati O. Museums and Collections. Sinapsis. [in Spanish] 2000;3:15-16. 10. Conde-Salazar L, Heras-Mendaza F. The Olavide Museum. Past, present, and future. Actas Dermosifiliogr. [in Spanish] 2011;102(2):79-85.

11. Conde-Salazar L, Heras F. Olavide Museum (I): history. Actas Dermosifiliogr. 2007;98(1):65-68.

12. Conde-Salazar L, Heras-Mendaza F. New information concerning the history of the Olavide Museum and its wax models. Actas Dermosifiliogr. [in Spanish] 2012;103(7):561-566.

13. Conde-Salazar L, Heras-Mendaza F. Olavide Museum (III): recovery. Actas Dermosifiliogr. 2007; 98(3):209-212.

14. http://museoolavide.aedv.es/obras-olavide/moulages

15. Kićevac M. Clinic for Skin and Venereal Diseases. School of Medicine of the Belgrade University from 1920-1935. [in Serbian] 1935:125-131.

16. Kićevac M. Prof. Dr. Đorđe Đorđević. Srp Arh Celok Lek. [in Serbian] 1936;38(5):447-9.

17. Medenica L, Lalevic-Vasic B, Skiljevic D. The Belgrade dermatovenereologic moulage collection: past and present. J Eur Acad Dermatol Venereol. 2008;22(8):937942.

18. Atherton DJ. Joseph Towne: wax modeler extraordinary. J Am Acad Dermatol. 1980;3(3):311-6.

19. Joshi R, D'Costa G, Kura MM. Moulages of J. J. Hospital. Indian J Dermatol Venereol Leprol. 2010;76(5):583-8 